\title{
How Will Indonesia Pay For Early Childhood Education Services?
}

\author{
Nur Ambia Arma \\ Faculty of Public Administration \\ Brawijaya University \\ Malang, Indonesia \\ ambiaarma.aa@gmail.com
}

\begin{abstract}
Early childhood education fosters skills and expand knowledge of a citizen so that later become productive citizens. It is thus important for the Indonesian government to provide services for early childhood education not only to the primary and secondary education. This research using descriptive statistical analysis to see how the Indonesian government pay early childhood education services through an administrative data sets from 2011 to 2015 . Our findings suggest that the Indonesian government financing provided to early childhood education is very minimal compared to the amount of funding for primary and secondary education. Average cost for early childhood education from 2011 to 2015 is less than one percent of the total financing of educational affairs. Unlike the case with primary education that reach twenty to thirty nine percent, as well as for secondary education reach nine percent.
\end{abstract}

Keywords-early childhood education; public service; education funding

\section{INTRODUCTION}

The importance of early childhood education has become a concern in the international community since the meeting of the World Education Forum in 2000 in Dakar. Early childhood education will develop a brain that foster skills and character that will transform a knowledge into a competence and will become productive citizens (Depdiknas USPN, 2004: 4; Calman and Whelan, 2005; Heckman, 2012; MacEwan, 2013). Therefore, the purpose of the development of early childhood education is the responsibility of the government to be aware of. In accordance with the mandate of the Act 1945 that every citizen is obliged to get an education and the government must finance at least $20 \%$ of the budget revenue and expenditure.

The world education forum agreed there should be a treatment to expand and improve the overall care and early childhood education (ECCE), especially for children who are less fortunate (musbikin, 2010). As Finance is complex and important for the development of a quality early childhood education system (UNICEF, 2011).

In this paper, we look at the budget of early childhood education provided by the Indonesian government. We intend to understand how Indonesia pay early childhood education services and how many contributions that have been given to the total central government funding of education affairs in Indonesia by comparing budget of primary school and secondary school. We investigate this financing through administrative data of early childhood education in Indonesia with a descriptive statistical analysis.

\section{DISCUSSION}

\section{A. Early Childhood Education (ECE)}

People carry out early childhood education before they enter primary school (Depdiknas USPN, 2004: 4). In essence, early childhood education is a series of efforts systematic and programmed in order to develop in children from birth to the child at the age of six years are accomplished by providing stimulation of education to help the growth and development of the body and spiritual children to someday have the world's readiness to enter further education (Depdiknas USPN, 2004:). Basically, early childhood education has the objective to develop and steer and provide stimulus to education in children early age from the age of 0 months to 6 years old before entering elementary school in order to help the growth and development of children to be able and ready to enter the education further. Because in childhood, they have brains that are still perfect and is expected to be optimal.

Early childhood education has grown from year to year. As this fact is seen through the rate of participation in early childhood education is increased as shown in Table 1 below:

Table 1. Number of Institutions and Students by School Status

\begin{tabular}{|l|l|l|l|l|}
\hline Year & Public & Private & Public & Private \\
& Schools & Schools & Students & Students \\
\hline 2011 & 2.083 & 68.834 & 131.309 & 3.481 .132 \\
\hline 2012 & 2.637 & 68.719 & 164.569 & 3.829 .360 \\
\hline 2013 & 2.654 & 72.328 & 172.222 & 4.002 .561 \\
\hline 2014 & 2.764 & 76.604 & 281.653 & 4.076 .572 \\
\hline 2015 & 3.186 & 82.213 & 309.255 & 4.186 .177 \\
\hline
\end{tabular}


Table 1 shows an increase in the number of institutions and number of students who participate in early childhood education from 2011 until 2015. This proves that early childhood education in Indonesia has been growing despite the downturn in the number of private institutions in 2012, but increased again in the next year. Percentage increase of institutions and students in kindergarten shown in fig. 1.

Fig. 1. Ratio of increasing number of institutions and kindergarten students

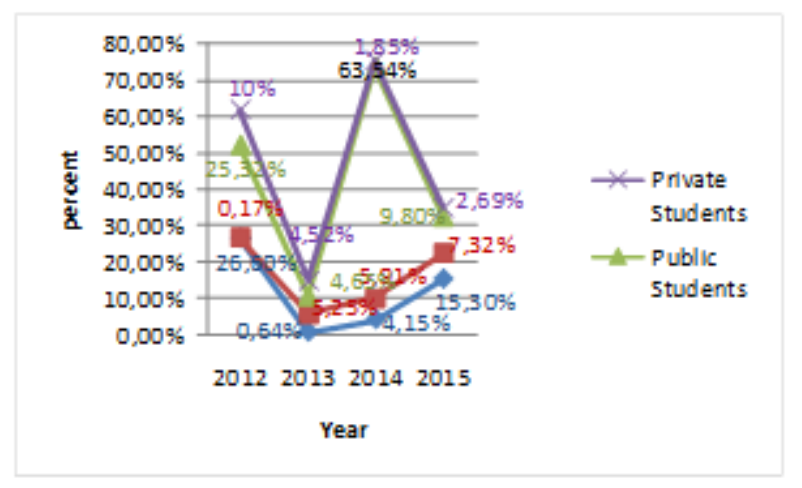

Fig. 1 shows that the ratio of institutions ECE in 2012 increased by $26.60 \%$ to a public institution. but for private institutions has decreased by $0.17 \%$. Although at private institutions has decreased in 2012 but rose again in 2013 amounted to $5.25 \%$ and for public institutions continue to increase by $0.64 \%$. In 2014 public institutions increased by $4.15 \%$ and the private sector amounting to $5.91 \%$, while in 2015 , public and private institutions increased respectively by $15.30 \%$ and $7.32 \%$. No different from the institution, to the ratio of students participating in ECE also increased. In 2012 each increase in public and private amounted to $25.32 \%$ and $10 \%$, in 2013 amounted to $4.65 \%$ and $4.52 \%$. 2014 has increased public high reached $63.54 \%$ and the private sector amounting to $1.85 \%$. 2015 also increased respectively to public and private sector amounting to $9.80 \%$ and $2.69 \%$.

\section{B. Early Childhood Education (ECE)}

The increasing number of institutions of early childhood education (ECE) and also the participating students should require significant costs in order to serve students who are the government's responsibility in the ministry of education as Law No. 23 of 2014 about Regional Government explained that one of the basic services mandatory government in order to improve the welfare of citizens and intelligence.

Service is an activity undertaken by a person or group of people with a particular runway where the level of gratification can only be felt by those who serve or served (Moenir, 2002: 26-27). While the public service is a service provision or serve a person for the purposes of another person or people who have

an interest in the organization in accordance with the basic rules and procedures determined (Kurniawan, 2005: 6). Law No. 25 of 2009 states that public service is an activity or series of activities in order to meet the needs of the service in accordance with the laws of every citizen and resident in the goods, services, and / or administrative services provided by public service providers.

Providing assistance in the financing of early childhood education has existed since 2002 as institutional aid fund early childhood which later changed as early childhood Operational Entity (BOP) in 2009 and in force today. BOP a financing aid for early childhood education provided by the central government through the budget revenue and expenditure affairs assigned to ministry of education early childhood education to control and manage the budget given. While the operational costs are the costs of materials or educational equipment consumables, and the indirect cost of providing education. Interest BOP relief assistance is to improve the quality of early childhood services in early childhood institutions have similar national ECE Unit Identification Number (NPSN).

\begin{tabular}{|l|l|l|}
\hline \multicolumn{2}{|c}{ Table 2. Education Budget From APBN } \\
\hline \multicolumn{1}{|c|}{ Budget } & $\begin{array}{c}\text { Total of } \\
\text { Expenditure on } \\
\text { Education Affairs }\end{array}$ \\
\hline 2011 & 290.319 .727 .000 & 107.676 .658 .574 .000 \\
\hline 2012 & 261.627 .280 .480 & 118.015 .850 .517 .446 \\
\hline 2013 & 676.293 .045 .000 & 126.569 .092 .910 .005 \\
\hline 2014 & 608.128 .700 .000 & 129.224 .906 .014 .000 \\
\hline 2015 & 713.570 .000 .000 & 155.064 .559 .108 .000 \\
\hline Primary & & \\
\hline 2011 & 22.460 .494 .964 .000 & 107.676 .658 .574 .000 \\
\hline 2012 & 32.144 .560 .985 .559 & 118.015 .850 .517 .446 \\
\hline 2013 & 31.100 .815 .001 .432 & 126.569 .092 .910 .005 \\
\hline 2014 & 30.529 .441 .417 .000 & 129.224 .906 .014 .000 \\
\hline 2015 & 61.437 .614 .457 .123 & 155.064 .559 .108 .000 \\
\hline
\end{tabular}

\section{Secondary}

\begin{tabular}{|l|l|l|}
\hline 2011 & 9.739 .623 .484 .000 & 107.676 .658 .574 .000 \\
\hline 2012 & 9.171 .847 .151 .539 & 118.015 .850 .517 .446 \\
\hline 2013 & 12.471 .057 .803 .233 & 126.569 .092 .910 .005 \\
\hline 2014 & 14.937 .570 .000 .000 & 129.224 .906 .014 .000 \\
\hline 2015 & 15.233 .652 .597 .890 & 155.064 .559 .108 .000 \\
\hline
\end{tabular}

The amount of aid funding for early childhood education in Indonesia is low. The low budget given evidence that in matters of early childhood education is still not a central concern of government Indonesia. It can be seen from the amount of the contribution of early childhood education budget to the total budget on education affairs is minimal and very muchthe difference between primary and secondary education. In Fig. 2. It is shown that the contribution of early childhood education budgets are under $1 \%$ of the total budget for education affairs. While the contribution of basic education 
budget reached about $20 \%$ to $40 \%$ of the total budget for education and secondary education to reach 7 to $11 \%$. The difference is very far shows that early childhood education has not become a major priority that is required as well as primary and secondary education has been required.

Calman and Whelan (2005) observes that there is a benefit of early childhood education quality as well as being an economic investment, such as: early childhood education high quality will make them to pay more taxes and the level of crimes is low in the future. Samuelsson and Kaga (2008), believes that educating a sustainable manner should start early. In childhood, children develop basic values, attitudes, skills, behaviors and habits of those who may be prolonged. Children can take cultural messages about wealth and inequality because early childhood education is about laying the foundation of intellectual, psychological, emotional, social and strength physical for life-long development and learning and also has great potential in encouraging sustainable development behavior. Some of the potential that can be generated through early childhood education is expected to be

Fig. 2. ECE, elementary and junior secondary budget contributions

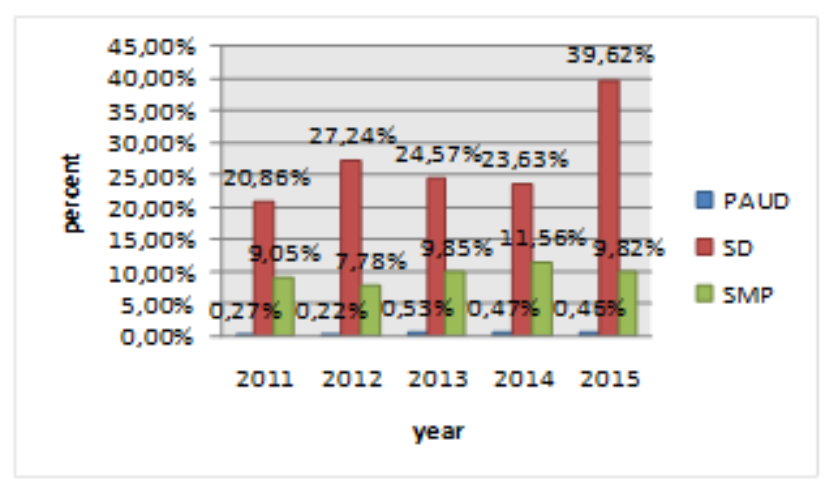

\section{CONCLUSION}

Early childhood education requires more attention in order to make the citizens of Indonesia to grow in quality and be productive. Individual's quality and productivity are believed to have a beneficial impact on the country in the future. Special attention should be given by the government in the provision of services in the form of a budget as mandated by the Constitution of the State to provide education to the community in order to realize social welfare and the intellectual life of the nation. an encouragement Indonesian government and citizens to be able to understand and support the early childhood education program.

The important of early childhood education has become a concern in the international community, since the meeting of the World Education Forum in 2000 in Dakar, Senegal in the discussion resulted in six agreements (TheDakar Frame Work for Action Education forAll) which is one of the agreement states that there should be treatment to expand and improve the overall early childhood care and education (ECCE), especially for children who are very vulnerable and disadvantaged because of poverty (UNICEF, 2012).

Early childhood education has become the world's attention, it is thus expected that Indonesia also provide more support. The existence of this study may not be the last, and is expected to evolve continuously to make improvements so that the greater the likelihood of early childhood education will be part of the education that must be implemented by every citizen of Indonesia. In the present study has limitations to the data, so only the form of the overall budget

\section{References}

[1] Moenir, A.S. 2002. Manajemen Pelayanan Umum di Indonesia. Jakarta: Bumi Aksara

[2] Depdiknas USPN, 2004. Kurikulum Taman Kanak-Kanak (TK) dan Raudhatul Athfal (RA). Jakarta: Direktorat Jendral Pendidikan Dasar dan Mengah

[3] Calman, Leslie J and Whelan, Linda Tarr. 2005. Early Childhood Education For All, A Wise Investment. New York: A conference sponsored by Legal Momentum's Family Initiative and The MIT Workplace Center, retrieved from http://www.familyinitiative.org

[4] Kurniawan, A. 2005. Transformasi Pelayanan Publik. Yogyakarta: Pembaruan

[5] Samuelsson, Ingrid P. and Kaga, Yoshie. 2008. The Contribution of Early Childhood Education To A Sustainable Society. Paris: UNESCO

[6] UNICEF, 2011. A Framework and Toolbox for Monitoring and Improving Quality in Early Childhood Education. Author. Retrieved from http://www.unicef.org/ceecis/early_childhood_20562.html.

[7] Heckman, James J. 2012. Invest in Early Childhood Development: Reduce Deficits, Strengthen the Economy. Chicago: artikel economics and expert in the economics of human development. Retrieved from www.heckmanequation.org

[8] UNICEF. 2012. Pendidikan dan Perkembangan Anak Usia Dini. Ringkasan Kajian, retrieved from https://www.unicef.org/indonesia/id/A3 B Ringkasan_Kajian_Pendidik an.pdf

[9] MacEwan, Arthur. 2013. Early Childhood Education As An Essential Component Of Economic Development. Amherst: University of Massachusetts 